\title{
Determination of Silver in Geological Samples by Dynamic Reaction Cell Inductively Coupled Plasma Mass Spectrometry After Extraction From Boiling aqua regia
}

\author{
Jiangyi Zhang ${ }^{\mathrm{a}, \mathrm{b}^{*}}$, Yanhui Dong ${ }^{\mathrm{a}, \mathrm{b}}$, and $\mathrm{Zhifang} \mathrm{Xu}^{\mathrm{a}, \mathrm{b}}$ \\ ${ }^{a}$ Key Laboratory of Shale Gas and Geoengineering, Institute of Geology and Geophysics, \\ Chinese Academy of Sciences, Beijing 100029, P.R. China \\ ${ }^{b}$ University of Chinese Academy of Sciences, Beijing 100049, P.R. China
}

\section{INTRODUCTION}

In the study of geochemical prospecting and geochemical partitioning, the concentration of silver (Ag) in such samples can be used as an important index of geochemical characteristics for the analysis of geochemical anomalies to understand element enrichment, to explore causes, and to establish the criteria of geological and geochemical ore-prospecting, etc. However, $\mathrm{Ag}$ is a low-abundance (to $\mathrm{ng} \mathrm{g}^{-1}$ levels) element in the earth's crust (1-2) and very difficult to quantify accurately.

Nowadays, atomic absorption spectrometry (AAS) (3-5) and inductively coupled plasma optical emission spectrometry (ICP-OES) (6-8) are the commonly used analytical techniques for the determination of trace Ag in geological samples. Compared to AAS and ICP-OES, inductively coupled plasma mass spectrometry (ICP-MS) is widely used for the determination of trace levels of $\mathrm{Ag}$ and other metals (9-10) owing to its high sensitivity, multielement capability, and very wide dynamic range (11-12). However, in most geological samples, the abundance of zirconium ( $\mathrm{Zr}$ ) is several orders of magnitude higher (2300 times) than the abundance of $\mathrm{Ag}$ in the earth's crust (2). In addition, the oxides of $\mathrm{Zr}\left({ }^{90} \mathrm{Zr}^{17} \mathrm{O}^{+}\right.$, $\left.{ }^{91} \mathrm{Zr}^{16} \mathrm{O}^{+},{ }^{91} \mathrm{Zr}^{18} \mathrm{O}^{+}\right)$, the hydroxides of $\mathrm{Zr}\left({ }^{90} \mathrm{Zr}^{16} \mathrm{OH}^{+},{ }^{90} \mathrm{Zr}^{18} \mathrm{OH}^{+}\right.$,

$\left.{ }^{91} \mathrm{Zr}^{17} \mathrm{OH}^{+}\right)$as well as the oxides

*Corresponding autbor.

E-mail: zhangjiangyi@mail.iggcas.ac.cn

Tel: (+86) 10-82998557

Fax: (+86) 10-62010846

\section{ABSTRACT}

In this work, a valid method was developed for the determination of Ag in large geological samples using dynamic reaction cell (DRC) ICP-MS after extraction from boiling aqua regia. In the extraction procedure, over $90 \%$ of the $\mathrm{Zr}$ and $\mathrm{Nb}$ which produces oxide and hydroxide interferences was removed. The residual $\mathrm{Nb}$ oxide and Zr-hydroxide interferences were eliminated by DRC technology. Under the optimized $\mathrm{O}_{2}$ flow rate $\left(2.7 \mathrm{~mL} \mathrm{~min}^{-1}\right)$, the background signal was reduced by two orders of magnitude at $\mathrm{m} / \mathrm{z} 109$ and the limit of quantitation (LOQ 10д) for ${ }^{109} \mathrm{Ag}^{+}$was 0.2 $\mathrm{ng} \mathrm{g}^{-1}$. The proposed method was applied to the direct determination of Ag in 10 different geological standard reference materials (SRMs), and the results were in good agreement with the certified values.

and hydroxides of yttrium (Y) and niobium $(\mathrm{Nb})\left({ }^{89} \mathrm{Y}^{18} \mathrm{O}^{+},{ }^{89} \mathrm{Y}^{17} \mathrm{OH}^{+}\right.$, ${ }^{93} \mathrm{Nb}^{16} \mathrm{O}^{+}$) interfere with the accurate determination of $\mathrm{Ag}$ by ICP-MS.

In order to obtain reliable results, the interferences have to be eliminated and several methods have been employed. Mathematical correction equation is a common method, but it is unable to solve the multiple atomic interference problems of $\mathrm{Ag}$ and could lead to significantly erroneous results (1314). Using high-resolution sector field ICP-MS is one possible method for eliminating the interferences but the resolution required to remove the oxide and hydroxide interferences on the isotopes of silver are $23,600\left({ }^{107} \mathrm{Ag}\right)$ and 31,457 $\left({ }^{109} \mathrm{Ag}\right)(15-16)$; however, both values are significantly higher than the currently available high-resolution instruments can achieve $(\mathrm{m} / \triangle \mathrm{m}=\sim 10,000)$. The use of a matrix separation/pre-concentration procedure is inevitable and many researchers have established methods which can remove the interfering elements effectively (1721). However, these separation methods are either time-consuming or require a special equipment setup, and pose higher risks of contamination. Fortunately, Li et al. (22) established a simple method to minimize the interferences of $\mathrm{Zr}$, $\mathrm{Nb}$, and Mo in the sample preparation procedure based on their extraction in boiling aqua regia in an open vessel, and obtained satisfactory recoveries of trace Ag. However, there are still some problems in this procedure since the residual concentrations of $\mathrm{Zr}$ and $\mathrm{Nb}$ are hundreds of times higher than that of Ag which can result in positive bias. Recently, Guo et al. (23) reported a method based on ionmolecule reactions in a dynamic reaction cell (DRC ${ }^{\mathrm{TM}}$ ) to eliminate oxide interferences and the direct determination of ultra-trace silver in soils. Although the interference signal can be reduced up to 100 -fold, the capability of this method to eliminate interferences is limited due to the high $\mathrm{Zr}$ and $\mathrm{Nb}$ values in geological samples. This method also requires a special sample digestion device which, after repeated addition of $\mathrm{HNO}_{3}$ to evaporate and 
remove $\mathrm{Si}$ and $\mathrm{HF}$ after the sample digestion is completed, can pose a high risk of contamination or lose target analytes. Thus, this method is not suitable for the determination of Ag in large geological samples.

In this work, a method for the direct determination of trace $\mathrm{Ag}$ in geological samples based on DRCICP-MS (in combination with sample pre-treatment by extraction in boiling aqua regia) was investigated. It was found that the oxide and hydroxide interference from $\mathrm{Zr}$ and $\mathrm{Nb}$ can be effectively eliminated. The established method was verified by determining trace Ag in 10 geological standard reference materials (SRMs) with good results.

\section{EXPERIMENTAL}

\section{Instrumentation}

A PerkinElmer ${ }^{\circledR}$ ELAN $^{\circledR}$ DRC $^{\mathrm{TM}}$-e (Dynamic Reaction Cell ${ }^{\mathrm{TM}}$ ) ICP-MS instrument (PerkinElmer, Inc., Shelton, CT, USA) was used and is described in detail elsewhere (24, $25)$. The typical instrument configurations and operating parameters used in this work are summarized in Table I.

\section{Reagents, Chemicals, and Stock Solutions}

The oxygen $\left(\mathrm{O}_{2}\right)(99.999 \%)$ was purchased from Praxair Investment Co., Ltd., P.R. China). High-purity water $\left(18.2 \mathrm{M} \Omega-\mathrm{cm}^{-1}\right)$ was used throughout this work and was obtained from a Millipore ${ }^{\circledR}$ Milli-Q ${ }^{\circledR}$ Direct 8 water purification system (Millipore Corporation, France). Nitric acid $\left(\mathrm{HNO}_{3}, 65-70 \%, \mathrm{w} / \mathrm{w}\right.$, 99.9999\%) and hydrochloric acid ( $\mathrm{HCl}, 99.999 \%)$ were purchased from Beijing Chemical Reagent Research Institute. The signal element stock solutions (Ag, $\mathrm{Zr}$, Nb, and $\mathrm{Rh}$ ) were purchased from the National Center for Analysis and Testing of Steel Materials, P.R. China. Three soils, three sediments and four rock SRMs (GBW07425, GBW07429, and GBW07451 Soil,
GBW07301a, GBW07302, and GBW07303 Sediment, GBW07103, GBW07105, GBW07110, and GBW07113 Rock) were used to assess the accuracy of this method (purchased from the Institute of Geophysical and Geochemical Exploration, Langfang, P.R. China).

\section{Sample Preparation by Extrac- tion in Boiling aqua regia}

A homogenized sample of $0.5000 \mathrm{~g}$ was weighed into a $25-\mathrm{mL}$ polyethylene tube to which $6.0 \mathrm{~mL}$ of aqua regia was added. The tube was capped and placed in a water bath at $95^{\circ} \mathrm{C}$ for 2 hours. After cooling to room temperature, the solution was diluted to $25 \mathrm{~mL}$ with high purity water and centrifuged to remove the undissolved solid particles. A 2.0-mL amount of supernatant liquid was transferred into a $25-\mathrm{mL}$ polyethylene tube and $0.25 \mathrm{~mL}$ of $1 \mathrm{mg} \mathrm{L}^{-1} \mathrm{Rh}$ internal standard solution was added. The final solution was diluted to $25 \mathrm{~mL}$ with high purity water.

\section{RESULTS AND DISCUSSION}

\section{Elimination of Interferences}

It is well known that the oxides and hydroxides of $\mathrm{Zr}$ and $\mathrm{Nb}$ severely interfere in the ICP-MS determination of $\mathrm{Ag}$ in geological samples. Fortunately, $\mathrm{Zr}$ and $\mathrm{Nb}$ can be eliminated by an incomplete digestion technique based on the extraction in boiling aqua regia (22, 26-27). Zr and $\mathrm{Nb}$ are lithophilic elements which are strongly bound to silicate minerals and cannot be dissolved completely in this process (26). An extraction procedure separates most of the $\mathrm{Zr}$ and $\mathrm{Nb}$ matrix (>90\%) from the Ag analyte, and thus result in satisfactory recoveries (22). Although most of the interfering elements are removed by this procedure, the residual concentrations were found up to several hundredfold higher (210-fold, 259-fold, and 509-fold) than that of $\mathrm{Ag}$ (shown in Table II) which can result in significant positive bias.

TABLE I

Instrumental Operating Parameters

\begin{tabular}{ll}
\hline ICP-MS & PerkinElmer ${ }^{\circledR} \mathrm{ELAN}^{\circledR} \mathrm{DRC}^{\mathrm{TM}}-\mathrm{e}$ \\
Sample introduction & PFA-400 Micro Flow nebulizer \\
Spray chamber & Cyclonic spray chamber (PC3 Peltier Chiller), \\
& room temperature \\
Injector tube & $1.0 \mathrm{~mm}$ i.d. quartz \\
RF power & $1350 \mathrm{~W}$ \\
Plasma gas flow & $16 \mathrm{~L} \mathrm{~min}^{-1}$ \\
Auxiliary gas flow & $1.0 \mathrm{~L} \mathrm{~min}^{-1}$ \\
Nebulizer gas flow & $0.78 \mathrm{~L} \mathrm{~min}^{-1}$ \\
O2 reaction gas flow & $2.7 \mathrm{~mL} \mathrm{~min}^{-1}$ \\
Rejection parameter, $\mathrm{q}$ & $0.8 \mathrm{for}^{109} \mathrm{Ag}^{+}, 0.25$ for ${ }^{103} \mathrm{Rh}^{+}$ \\
Rejection parameter, a & 0 \\
Auto Lens & $\mathrm{On}$ \\
Dwell time & $50 \mathrm{~ms}^{+}$ \\
Sweeps & 32 \\
Readings & 1 \\
Replicate & 3 \\
Cones & $\mathrm{Ni}$ \\
Monitored ions & $109 \mathrm{Ag}^{+}$and ${ }^{103} \mathrm{Rh}^{+}$ \\
\hline
\end{tabular}


Fortunately, the interferences from the residual concentrations of $\mathrm{Zr}$ and $\mathrm{Nb}$ can be eliminated by using the DRC technique with $\mathrm{O}_{2}$ as the reaction gas. In this study, background equivalent concentration (BEC) was used as a criterion for the optimization of DRC conditions. Figure 1 shows the effect of the $\mathrm{O}_{2}$ gas flow rate on the signals of the matrix blank and $1 \mathrm{ng} \mathrm{mL} \mathrm{m}^{-1} \mathrm{Ag}+$ matrix blank at $\mathrm{m} / \mathrm{z}$ 109. A mixture of $500 \mathrm{ng} \mathrm{mL}^{-1} \mathrm{Nb}$ and $2000 \mathrm{ng} \mathrm{mL}^{-1}$ $\mathrm{Zr}$ was used as the matrix blank to simulate the interfering elements on Ag determination. As shown in Figure 1, at a low $\mathrm{O}_{2}$ flow rate there was a sharp increase in the signals of the interfering species at $\mathrm{m} / \mathrm{z}$ 109. With increasing $\mathrm{O}_{2}$ flow rates, the background signal decreased rapidly at $\mathrm{m} / \mathrm{z} 109$ (Figure 1 ). The optimum $\mathrm{O}_{2}$ flow rate was selected at $2.7 \mathrm{~mL} \mathrm{~min}^{-1}$ and the signal at $\mathrm{m} / \mathrm{z} 109$ generated by the interfering ions was reduced by two orders of magnitude and the background equivalent concentration (BEC) was $0.03 \mathrm{ng} \mathrm{mL}^{-1}$.

The optimization profile (Figure 2) indicates that the interfering species decreased with increasing $\mathrm{O}_{2}$ gas flow rates. The success of the reaction is based on the generation of multiple oxide/hydroxide species and is shown as follows:

$\mathrm{M} \rightarrow \mathrm{MO}^{+} / \mathrm{MOH}^{+} \rightarrow \mathrm{MO}_{2}^{+} / \mathrm{MO}_{2} \mathrm{H}^{+} \rightarrow \mathrm{MO}_{3}^{+} / \mathrm{MO}_{3} \mathrm{H}^{+}$

TABLE II

Results for $\mathrm{Zr}$ and $\mathrm{Nb}$ Level in Three Geological SRMs Using Boiling Aqua Regia

\begin{tabular}{|c|c|c|c|c|c|c|c|}
\hline \multirow{2}{*}{$\begin{array}{l}\text { Geological } \\
\text { SRMs }\end{array}$} & \multicolumn{2}{|c|}{$\mathrm{Zr}\left(\mu \mathrm{g} \mathrm{g}^{-1}\right)$} & \multicolumn{2}{|c|}{$\mathrm{Nb}\left(\mu \mathrm{g} \mathrm{g}^{-1}\right)$} & \multirow{2}{*}{$\begin{array}{c}\mathrm{Ag}\left(\mu \mathrm{g} \mathrm{g^{-1 }}\right) \\
\text { Certified }\end{array}$} & \multirow[t]{2}{*}{$\mathrm{Zr} / \mathrm{Ag}^{\mathrm{a}}$} & \multirow[t]{2}{*}{$\mathrm{Nb} / \mathrm{Ag}^{\mathrm{a}}$} \\
\hline & Certified & Extraction & Certified & Extraction & & & \\
\hline GBW07425 & & & & & & & \\
\hline $\begin{array}{l}\text { Soil } \\
\text { GBW07302 }\end{array}$ & $270 \pm 9$ & $25.4 \pm 0.5$ & $13.8 \pm 0.6$ & $1.2 \pm 0.1$ & $0.098 \pm 0.007$ & 259 & 12 \\
\hline Sediment & $460 \pm 40$ & $33.6 \pm 0.4$ & $95 \pm 9$ & $6.65 \pm 0.04$ & $0.066 \pm 0.015$ & 509 & 100 \\
\hline Rock & $403 \pm 35$ & $16.8 \pm 0.06$ & $34.3 \pm 3.1$ & $2.31 \pm 0.03$ & $0.08 \pm 0.02$ & 210 & 28 \\
\hline
\end{tabular}

${ }^{\mathrm{a}}$ The value of $\mathrm{Zr} / \mathrm{Ag}$ and $\mathrm{Nb} / \mathrm{Ag}$ is that the value of extraction of $\mathrm{Zr}$ and $\mathrm{Nb}$ divided by the certified value of $\mathrm{Ag}$.

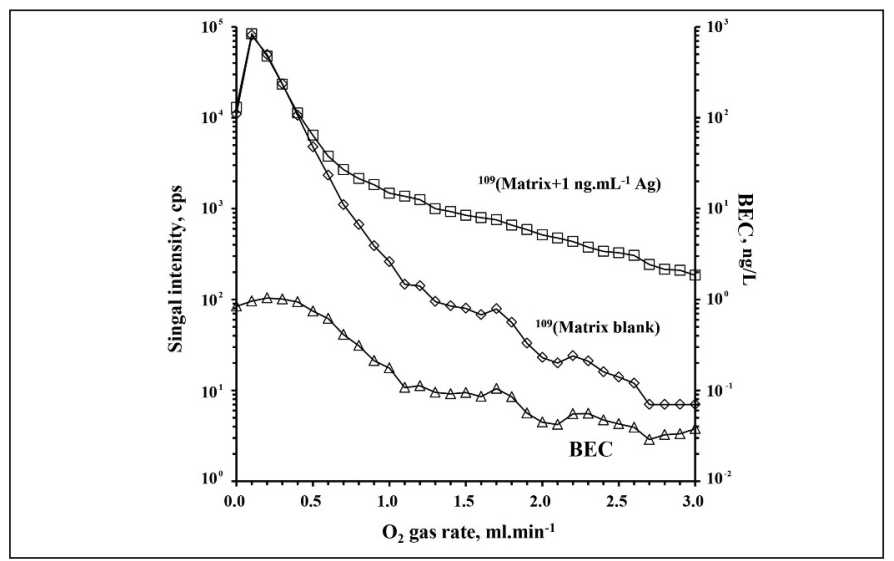

Fig. 1. Effects of $\mathrm{O}_{2}$ gas flow rate on signal intensity of ${ }^{109} \mathrm{Ag}+$ matrix, matrix blank, and background equivalent concentration (BEC). The concentration of $\mathrm{Ag}$ was $1 \mathrm{ng} \mathrm{mL}^{-1}$, a solution of $500 \mathrm{ng} \mathrm{mL}^{-1} \mathrm{Nb}$ and $2000 \mathrm{ng} \mathrm{mL}^{-1} \mathrm{Zr}$ was used as matrix blank.

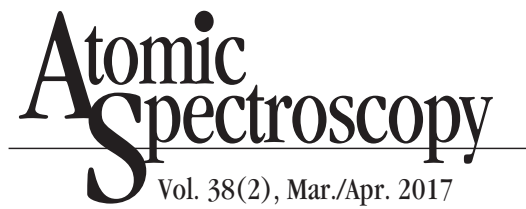

Therefore, the oxide/hydroxide interferences $\left({ }^{90} \mathrm{Zr}^{18} \mathrm{O}^{+},{ }^{90} \mathrm{Zr}^{18} \mathrm{OH}^{+}\right.$, ${ }^{93} \mathrm{Nb}^{16} \mathrm{O}^{+}$) on the ${ }^{109} \mathrm{Ag}^{+}$determination could be completely removed with high $\mathrm{O}_{2}$ flow rates $(2.7 \mathrm{~mL}$ $\min ^{-1}$ ).

\section{Analytical Performance}

Under the optimized experimental conditions, the limit of quantitation (LOQ, 10 times the standard deviation of the procedural blank) was $0.2 \mathrm{ng} \mathrm{g}^{-1}$ for $\mathrm{Ag}$. The LOQ is expressed as the concentration in the sample. The relative standard deviation (RSD) was calculated based on triplicate sample digestions and analyses, and was generally less than $5 \%$.

\section{Analysis of Geological Standard Reference Materials (SRMs)}

In order to investigate the suitability, accuracy, and precision of the proposed method, 10 different types of geological SRMs, which included four rocks, three sediments, and three soils, were analyzed. As can be seen from Table III, the obtained values of the established method (DRC-ICP-MS), without any correction, are in good agreement with the certified values. However, for the low values of $\mathrm{Zr} / \mathrm{Ag}$ and $\mathrm{Nb} / \mathrm{Ag}$ in GBW07303, the determi- 
nation values using conventional ICP-MS and DRC-ICP-MS all agreed with the certified values. For the high values of $\mathrm{Zr} / \mathrm{Ag}$ and $\mathrm{Nb} / \mathrm{Ag}$ in GBW07105 and GBW07301a, respectively, the results by conventional ICP-MS method are larger han the Ag certified values, which is due to the interference of $\mathrm{Zr}$ and $\mathrm{Nb}$ and. fortunately, can be solved by using the proposed method.

\section{CONCLUSION}

A method for the DRC-ICP-MS determination of trace Ag in geological samples after extraction in boiling aqua regia was developed. The significant oxide and hydroxide interferences from $\mathrm{Zr}$ and $\mathrm{Nb}$ were successfully eliminated by the proposed method. This method is much simpler than the conventional methods based on pre-concentration and separation, and has great potential for the direct determination of trace levels of $\mathrm{Ag}$ in a broad range of geological samples.

\section{ACKNOWLEDGMENTS}

This work was supported by the Youth Innovation Promotion Association CAS (Grant No. 2016063) and the Strategic Priority Research
Program of the Chinese Academy of Sciences (Grant No. XDB01020300).

Received September 27, 2016.

\section{REFERENCES}

1. S. Gao, T. C. Luo, B. R. Zhang, H. F. Zhang, Z. D. Zhao and Y. K. Hu, Geochim. Cosmochi. Ac. 62, 1959 (1998)

2. R. L. Rudnick and S. Gao, Treatise on Geochemistry. Amsterdam: Elsevier (2003), pp. 1-70.

3. G. Chakrapani, P. L. Mahanta, D. S. R. Murty and B. Gomathy, Talanta 53, 1139 (2001).

4. I. M. Dittert, D. L. G. Borges, B. Welz, A. J. Curtius and H. Becker-Ross, Microchim. Acta 167, 21 (2009).

5. Y. Cao, P. Wu, W. Li, Y. L. Xuan and X. D. Hou, Talanta 81, 586 (2010).

6. Y. S. Chung and R. M. Barnes, J. Anal. Atom. Spectrom., 3, 1079 (1988).

7. Y. C. Qing, Y. P. Hang, R. Wanjaul, Z. C. Jiang and B. Hu, Anal. Sci. 19,1417 (2003).

8. A. R. Jackbson, M. B. Mcbride, P. Baveye and T. S. Steenhuis, Sci. Total Environ. 345, 191 (2005).

9. Z. C. Wang, H. Becker and F. Wom- bacher, Geostand. Geoanal. Res. 39, 185 (2015).

10. R. M. Gaschnig, R. L. Rudnick and W. F. McDonough, Geostand. Geoanal. Res. 39, 371 (2015).

11. P. F. Hoekstra, B. M. Braune, B. Elkin, F. A. J. Armstrong and D. C. G. Muir, Sci. Total Environ. 309, 81 (2003).

12. M. Krachler and W. Shotyk, Sci. Total Environ. 407, 89 (2009).

13. J. Y. Hu, Z. Liu and H. Z. Wang, Anal. Chim. Acta., 451, 329 (2002).

14. X. L. Liu, W. J. Sun, T. Y. Wen, T. F. Wang, W. Z. Sun, Y. X. Li and J. Guo, Chinese J. Anal. Chem. 43, 1371 (2015).

15. L. A. Simpson, M. Thomsen, B. J. Alloway and A. Parker, J. Anal. At. Spectrom. 16, 1375 (2001).

16. M. Moldovan, E. M. Krupp, A. E. Holliday and O. F. X. Donard, J. Anal. At. Spectrom. 19, 815 (2004).

17. J. Xu, Z. C. Hu, Y. S. Liu, S. H. Hu, H. L. Yuan and S. Gao, Chinese J. Anal. Chem. 36, 1493 (2008).

18. J. S. Becker, C. Pickhardt and W. Pompe, Int. J. Mass Spectrom. 237, 13 (2004).

19. L. Yang and R. E. Sturgeon, J. Anal. At. Spectrom. 17, 88 (2002).

20. C. Moor, P. Boll and S. Wiget, Fre-

TABLE III

Ag in Geological SRMs $\left(\mu \mathrm{g} \mathrm{g}^{-1}\right)$ by Standard ICP-MS Mode and Proposed DRC-ICP-MS

\begin{tabular}{lccccc}
\hline SRMs & Zr/Ag & Nb/Ag & \multicolumn{3}{c}{ Ag $\left(\mu g \mathrm{~g}^{-1}\right)(\mathrm{Mean} \pm \mathrm{SD})$} \\
& & & ICP-MS & Proposed Method & Certified \\
\hline GBW07425, soil & 2755 & 140 & $0.112 \pm 0.004$ & $0.098 \pm 0.005$ & $0.098 \pm 0.007$ \\
GBW07429, soil & 1813 & 124 & $0.18 \pm 0.03$ & $0.14 \pm 0.01$ & $0.15 \pm 0.02$ \\
GBW07451, soil & 3445 & 208 & $0.108 \pm 0.005$ & $0.073 \pm 0.004$ & $0.074 \pm 0.006$ \\
GBW07301a, sediment & 9411 & 911 & $0.221 \pm 0.008$ & $0.035 \pm 0.008$ & $0.034 \pm 0.011$ \\
GBW07302, sediment & 6969 & 1439 & $0.114 \pm 0.008$ & $0.066 \pm 0.012$ & $0.066 \pm 0.015$ \\
GBW07303, sediment & 390 & 27 & $0.60 \pm 0.02$ & $0.59 \pm 0.05$ & $0.59 \pm 0.07$ \\
GBW07103, rock & 5060 & 1212 & $0.095 \pm 0.007$ & $0.032 \pm 0.006$ & $0.033 \pm 0.010$ \\
GBW07105, rock & 6925 & 1700 & $0.103 \pm 0.008$ & $0.038 \pm 0.005$ & $0.040 \pm 0.012$ \\
GBW07110, rock & 1970 & 122 & $0.20 \pm 0.04$ & $0.16 \pm 0.02$ & $0.17 \pm 0.03$ \\
GBW07113, rock & 5037 & 428 & $0.14 \pm 0.05$ & $0.08 \pm 0.03$ & $0.08 \pm 0.02$ \\
\hline
\end{tabular}




\section{Appectroscopy \\ $\bigcirc$ Vol. 38(2), Mar./Apr. 2017}

sen. J. Anal. Chem. 359, 404 (1997).

21. K. Ndung'u, M. A. Ranville, R. P. Franks and A. R. Flegal, Mar. Chem. 98, 109 (2006).

22. Z. X. Li, L. P. Zhou and F. Tan, Microchim. Acta 156, 263 (2007).

23. W. Guo, S. H. Hu, J. Y. Zhang and H. F. Zhang, Sci. Total Environ. 409, 2981 (2011).

24. J. Y. Zhang, G. M. Li and W. Guo, At. Spectrosc. 35, 97 (2014).

25. J. Y. Zhang, X. J. Wang, Y. H. Dong, Z. F. Xu and G. M. Li, At. Spectrosc. 37, 1 (2016).

26. W. Guo, S. H. Hu, J. Y. Zhang, L. L. Jin, X. J. Wang, Z. L. Zhu and H. F. Zhang, J. Anal. At. Spectrom., 26, 2076 (2011)

27. Q. Xu, W. Guo, L. L. Jin, Q. H. Guo and $\mathrm{S}$. H. Hu, J. Anal. At Spectrom., 30, 2010 (2015). 